\title{
Pembelajaran Kontekstual di Masa Pandemi untuk Mengembangkan Spiritualitas Anak
}

\author{
Contextual Learning in the Pandemic Period to Develop Children's Spirituality
}

\begin{abstract}
Author:
Minggus

Affiliation:

Sekolah Tinggi Teologi

Berita Hidup Surakarta

nggimbs@gmail.com

Dates:

Submitted:

14 January 2021

Accepted:

3 April 2021

Published:

17 May 2021

DOI:

10.46494/psc.v17i1.126
\end{abstract}

\section{Copyright:}

(C) 2021. The Authors.

Licensee: Licensee:

PASCA. This work is

licensed under the

Creative Commons

Attribution-ShareAlike

4.0 International License.

\begin{abstract}
The spiritual dimension is part of the goals of national education. Meanwhile, teachers are understood as professional educators with the main task of implementing the national education system and objectives. However, the Covid-19 pandemic period forced changes in learning patterns that required an appropriate learning model. Writing using this literature research method aims to discuss the meaning of spirituality and provide an alternative learning model for efforts to develop children's spirituality during a pandemic. Contextual learning is a model that teachers should consider, because this model focuses on the uniqueness of children and the situations they face.

[Dimensi spiritual menjadi bagian dari tujuan pendidikan nasional. Sedangkan guru dipahami sebagai pendidik profesional dengan tugas utama melaksanakan sistem dan tujuan pendidikan nasional. Namun masa pandemi Covid-19 memaksa perubahan pola pembelajaran yang membutuhkan model pembelajaran yang sesuai. Tulisan dengan metode riset kepustakaan ini bertujuan membahas makna spiritualitas dan memberikan alternatif model pembelajaran bagi upaya mengembangkan spiritualitas anak di masa pandemi. Pembelajaran kontekstual menjadi model yang patut dipertimbangkan para guru, sebab model ini berfokus pada keunikan anak dan situasi yang dihadapinya.]
\end{abstract}

Research Contribution: The results of this study contribute to theology (operative), namely regarding the concept and practice of children's spirituality formation during the pandemic. In practical terms, this research also contributes to efforts to improve Christian Religious Education services for children with a choice of contextual learning models.

Keywords: spirituality, contextuality, distance education, pandemic, Christian Education.

\section{Pendahuluan}

Oalah satu sikap dasar yang harus dimiliki seorang anak untuk menjadi pribadi yang baik adalah mempunyai sikap dan nilai moral yang sesuai dengan etika keluarga, masyarakat dan agama. Upaya membangun sikap dan nilai moral pada anak membutuhkan proses bersama dan waktu terbaik. Para ahli sepakat pentingnya mengajarkan sikap dan nilai moral kepada anak sedini mungkin. 
Selain sesuai dengan kebutuhan anak di masa perkembangannya; juga berdampak baik pada pembentukan dan penguatan karakter anak di masa dewasanya. ${ }^{1}$ Menurut Havighurst setiap tahap pada usia perkembangan, anak mempunyai potensi untuk mengembangkan kemampuan hati nurani membedakan yang benar dan salah dalam bentuk yang paling sederhana. ${ }^{2}$ Misalnya mengucapkan terimakasih, memberikan salam, tidak berbuat curang dan lain-lain. Meskipun orang tua berperan besar, namun pengajaran di sekolah juga tidak kalah pentingnya. Apalagi pada tahap pendidikan dasar (5-12 tahun), anak sangat terbuka dengan pengajaran yang disampaikan gurunya.

Para guru mempunyai peran besar membangun sikap dan nilai moral anak di masa pendidikan awal. Itu sebabnya, karakter guru yang mengajar umumnya ramah dan menyenangkan, sehingga anak-anak lebih mudah menyerap kebaikan sikap dan moral melalui keteladanan mereka. 3 Keteladanan melalui contoh kebaikan dalam praktik hidup sehari-hari menjadi sarana pembelajaran yang tepat bagi anak 'memahami' moralitas. Para guru biasanya menjelaskan materi dengan cara memperagakan langsung di depan siswa apa yang dimaksud moralitas.

Namun harapan membangun sikap dan moral anak melalui tatap muka terganggu sejak merebaknya pandemi Covid-19. Kehidupan yang biasanya berlangsung normal dengan durasi kerja 8 (delapan) jam per hari, berubah mengikuti aturan pemerintah yang mengharuskan bekerja dari rumah, work from home. ${ }^{4}$ Keputusan pemerintah disusul dengan

\footnotetext{
${ }^{1}$ Robert W. Crapps, Perkembangan Keperibadian \& Keagamaan (Yogyakarta: Kanisius, 1994),11. 2 Elisabeth Hurlock, Psikologi Perkembangan: Suatu Pendekatan Sepanjang Rentang Kehidupan, ed. Ridwan Max Sijabat, Kelima. (Jakarta: Erlangga, 1980), 10.

3 Otib Satibi Hidayat, Metode Pengembangan Moral Dan Nilai-Nilai Agama, ed. Nurul Hikmah, Kesatu. (Banten: Universitas Terbuka, 2015), xi.
}

himbauan melakukan Social atau Physical Distancing yang tidak lagi memungkinkan kumpulan lebih dari 5 (lima) orang. Penerapan PSBB (Pembatasan Sosial Berskala Besar) meski dipertanyakan keefektivannya, namun secara tujuan dipahami senada dengan aturan sebelumnya, yaitu dalam rangka memutus penyebaran Covid-19.

Kementerian Pendidikan dan Kebudayaan memutuskan agar semua satuan pendidikan, dari PAUD sampai Perguruan Tinggi mengubah pembelajaran menjadi study from home. 5 Pembelajaran yang selama ini dilakukan dengan tatap muka, harus dialihkan dalam jaringan. Perubahan model pembelajaran dari konvensional menuju Cyber Pedagogy bukan tanpa konsekuensi. Bukan sekadar persoalan ketersediaan peralatan dan kualitas jaringan, tetapi juga bagaimana menyiapkan dan mengajarkan materi ajar dari format tatap muka menjadi daring tanpa mengurangi capaian pembelajaran yang ditetapkan.

Hasil survei UNESCO terkait sistem pendidikan selama pandemi di 59 negara dunia termasuk Indonesia menunjukkan terdapat kesenjangan kemampuan pendidik dalam menggunakan teknologi informasi dan komunikasi. ${ }^{6}$ Ada dua yang harus segera diatasi para pendidik: menyiapkan materi untuk siap disajikan secara daring dan penguasaan teknologi sebagai penunjang pembelajaran. Kegagalan menyiapkan atau menguasai akan berdampak pada proses belajar mengajar itu sendiri.

Di sisi lain, terdapat lebih dari 68 persen siswa Indonesia yang mengikuti pembelajaran jarak jauh. Namun, 77 persen responden guru

4 Zubi Mahrofi, "Indef: Himbauan Pemerintah Harus Jadi Perhatian Pengusaha," ANTARANEWS. 5 Pengelola Web Kemdikbud, "Kemendikbud Terbitkan Pedoman Penyelenggaraan Belajar Dari Rumah," Jakarta, 28 Mei 2020.

${ }^{6}$ Isniatun Munawaroh, "Tantangan Guru Digital Immigrant Saat Pandemi Covid-19," Krjogja.Com, . 
mengaku bahwa tidak semua peserta didik dapat berpartisipasi dalam pembelajaran jarak jauh. Penyebabnya beragam, mulai ketidaksiapan guru dalam penguasaan teknologi sampai keterbatasan orang tua menyediakan sarana pendukung seperti gawai, laptop, paket data, ketersediaan jaringan dan lain-lain; juga sebanyak 1 (satu) dari 3 (tiga) responden guru merasa dukungan orang tua masih kurang.7 Pada akhirnya kompleksitas persoalan di masa pandemi berpotensi menjadi kendala pembelajaran yang juga akan berdampak pada capaian proses belajar anak pada semua dimensi, salah satunya dimensi spiritualitasnya.

Pendidik harus menunjukkan profesionalitasnya dengan cara menerapkan model pembelajaran yang memungkinkan pencapaian tujuan di masa pandemi berlangsung maksimal dan terukur dengan baik. Terlebih lagi mempertimbangkan kebutuhan anak di usia perkembangannya sebagai dasar pembentukan spiritualitas pribadi di masa-masa berikutnya, maka seorang pendidik ditantang menerapkan model pembelajaran yang sesuai dengan situasi terkini. Salah satu model yang dipilih untuk dibahas dalam tulisan ini adalah model pembelajaran kontekstual.

\section{Metode}

Pendekatan yang dipakai dalam tulisan ini adalah riset kepustakaan. ${ }^{8}$ Pendekatan ini merupakan penilaian tertulis dari peneliti

\footnotetext{
7 Reni Susani, "Perhatikan, 3 Dampak Pandemi Covid-19 terhadap Anak," KOMPAS, last modified 2020, accessed September 23, 2020, https://lifestyle.kompasIbid..com/read/2020/05/ 12/ o85714720/ terhadap-anak?page=all.

8 Sonny Eli Zaluchu, "Metode Penelitian Di Dalam Manuskrip Jurnal Ilmiah Keagamaan,” Jurnal Teologi Berita Hidup 3, no. 2 (March 25, 2021): 249-266, https://ejournal.sttberitahidup.ac.id/index.php/jbh/article /view/93.
}

sebagai langkah awal untuk mengumpulkan jawaban secara pustaka dari persoalan yang sedang diteliti. 9 Riset kepustakaan digunakan dalam rangka mengumpulkan informasi dan data dengan bantuan berbagai macam sumber baca dari perpustakaan. ${ }^{10}$ Dengan demikian riset kepustakaan membatasi kegiatannya hanya pada sumber-sumber pustaka, tanpa melakukan survei lapangan. ${ }^{11}$ Idealnya riset pustaka pun bisa diperkuat dengan pengumpulan data lapangan. Namun para sarjana ada yang tidak sependapat tentang hal ini. Sebab tidak semua penelitian bidang studi menuntut data lapangan. Ada juga kondisi tertentu yang tidak memungkinkan observasi, seperti yang terjadi sekarang di masa pandemi. Tujuan penerapan pendekatan ini lebih kepada pengembangan, pendalaman atau kolaborasi dari teori yang sudah ada. ${ }^{12}$ Jadi dalam konteks ini, pendekatan yang mengedepankan penggunaan beragam sumber baca tanpa melakukan observasi dapat diterima sepenuhnya secara akademik.

\section{Pembahasan}

\section{Spiritualitas Kristiani}

KBBI online hanya menjelaskan makna "spiritual" sebagai "hal yang berhubungan dengan atau kejiwaan (rohani, batin)".13 Sementara Wesbter memaknai "spirituality" sebagai sesuatu yang dalam hukum gerejawi dipandang milik gereja atau milik para klerus, kepekaan atau keterikatan pada nilai-nilai

9 M. Sukri Nur dan Aep S. Uyun, Tinjauan Pustaka Sistematis (Bogor: Lakeisha, 2020), 31.

${ }_{10}$ Milya; Asmendri Sari, "Penelitian Kepustakaan

(Library Research) Dalam Penelitian Pendidikan

IPA,” Natural Science (2020). 42.

${ }_{11}$ Mestika Zed, Riset Kepustakaan (Jakarta:

Yayasan Obor Indonesia, 2008), 2; Nursapia

Harahap, "Penelitian Kepustakaan," IQRA 08, no.

01 (2014) diunduh 30 Desember 2020.

12 Zed, Riset Kepustakaan., 20.

13 Anonymous, "Spiritual," Kamus Besar Bahasa Indonesia, n.d. 
agama atau keadaan spiritual. ${ }^{14}$ Pengertian yang kurang lebih sama juga dimaknai Oxford Dictionary sebagai kualitas yang terhubung dengan agama dan jiwa/roh manusia. ${ }^{15}$ Keterbatasan makna kata "spiritualitas" di atas bisa jadi mewakili perdebatan atau ketidaksepakatan yang terjadi selama ini.

Secara umum perdebatan makna spiritualitas dalam kekristenan terbagi dua. Pertama, spiritualitas dipahami bukan sebagai pengembangan potensi penciptaan yang alamiah, tetapi sebagai pengalaman rohani yang menjadikan seseorang sesuai dengan kehendak Allah. Kemajuan rohani sebagai wujud spiritualitas yang tampak dipandang dari sudut pemulihan gambar Allah; bukan dari sudut pandang pemulihan manusia batiniah. ${ }^{16}$ Artinya, spiritualitas seseorang berfokus pada kesadaran akan dosa, penebusan dan pemulihan sebagai pribadi. Chan berpendapat, "Tekanan tradisi Kristen lebih banyak terletak pada transendensi Allah daripada imanensi Allah. ${ }^{17}$

Pandangan Chan yang demikian juga menempatkan makna dan wujud spiritualitas manusia lebih vertikalis. Pertanyaannya, apakah transendensi Allah bisa dilepaskan atau tanpa terkait dengan imanensinya? Jelas tidak bisa! Bukankah Allah keduanya? ${ }^{18}$ Pandangan dikotomi yang ambiguitas ini bersifat platonis. Surgawi adalah ideal, sementara yang ragawi/duniawi adalah dosa. Pandangan ini jelas ambigu karena faktanya hal-hal yang dituduh tidak ideal adalah realitas keseharian yang dibutuhkan. Bagaimana mengukur

${ }^{14}$ Anonymous, "Spirituality," Wesbter Dictionary, n.d.

15 Anonymous, "Spirituality," Oxford Learner's

Dictionary (Oxford, n.d.).

${ }^{16}$ Sonny Eli Zaluchu, "Spiritual Kristiani Di

Tengah Laju Peradaban Digital [Spiritual Christianity in the Middle of Digital Civilization]," Proceedings Seminar Nasional Fakultas Psikologi Universitas Kristen Satya Wacana dan Asosiasi Psikologi Kristiani [Proceedings of the National Seminar of the Satya Wacana Christian University Psychology Faculty and the Christian spiritualitas bila secara hakekat diyakini terpisah dari realitas keseharian?

Kedua, spiritualitas dipahami secara utuh. Pandangan ini dibangun dari kebenaran bahwa manusia ada karena nafas Allah (Kej. 2:7, nashama chay) yang menghidupkan. Roh Allah (Kej 1:2, ruwach elohiym) adalah Pribadi yang menciptakan manusia (Kej. 2:7). Heuken berpendapat spiritualitas manusia dibangun dari kebenaran bahwa manusia adalah makhluk rohani. ${ }^{19}$ Artinya, manusia adalah pribadi utuh (rohani dan jasmani), dicipta menurut gambar Allah dan dipanggil mewujudkan kehadiran Allah melalui relasi dengan Sang Sumber Kehidupan. Namun manusia berdosa dan gagal mencapai tujuan Allah yang berdampak pada rusaknya relasi manusia dengan Allah, sesama dan semesta (Kejadian 3).

Manusia yang berdosa tidak mungkin memulihkan dirinya. Allah dalam kemurahan hati-Nya lebih dulu (Kej. 3:8) menyapa dan memulihkan manusia seturut dengan gambarNya. Berangkat dari kebenaran ini, maka pembentukan spiritualitas manusia menekankan tindakan yang dimulai dari Allah (Efesus 2:8-10, “tetapi pemberian Allah"), dengan tujuan memulihkan relasi manusia dengan diri-Nya (internal), sesama dan semesta (eksternal). Dengan demikian spiritualitas merupakan cara mengamalkan kehadiran dirinya dalam kehidupan sebagai seorang beriman yang berusaha merancang dan menjalankan hidup sesuai dengan kehendak Allah. Dua hal yang dilakukan: memilih sesama

Psychology Association] 1, no. 1 (2019): 198-209, https://repository.uksw.edu/bitstream/123456789 /19648/1/PROS_Sonny Zaluchu_Spiritual Kristiani di Tengah Laju Peradaban Digital.pdf.

17 Simon Chan, Spiritual Theology. Studi

Sistematik Tentang Kehidupan Kristen

(Yogyakarta: Yayasan ANDI, 2002). 2.

18 Milard J. Erickson, Teologi Kristen (Malang:

Gandum Mas, 2003). 44.

19 Adolf Heuken, Spiritualitas Kristiani.

Pemekaran Hidup Rohani Selama Dua Puluh Abad (Yogyakarta: Yayasan Cipta Loka Caraka, 2002). 7. 
sebagai rekan seperjalanan, sekaligus meningkatkan komunikasinya dengan Tuhan. ${ }^{20}$

Spiritualitas yang holistik adalah pengembaraan untuk memperdalam kesediaan dan kepatuhan diri menanggapi kendali Allah atas diri dan kehidupan. ${ }^{21}$ Hal senada disampaikan Eka Darmaputera bahwa spiritualitas berhubungan dengan pengalaman keagamaan yang bersifat personal, sekaligus melibatkan sosial (komunitas). Agama bisa kehilangan spiritualitas atau kehangatannya. Sebaliknya, agama menjadi besar karena spiritualitas yang menyebar. Itu berarti agama tidak lain adalah penerusan pengalaman agamaniah yang melibatkan orang lain (komunitas). Penerusan pengalaman itu dilakukan melalui proses rutinisasi agar dapat dilanjutkan kepada orang lain melalui kolaborasi yang seimbang pada 3 (tiga) dimensi spiritualitas: kognitif, ekspresif dan praktis. ${ }^{22}$

Tidak benar bila tradisi Kristen hanya menekankan transendensi Allah. Keunikan tradisi spiritualitas kristiani terletak pada keseimbangan antara penekanan segi batiniah dan lahiriah; segi dalam dan luar. Sebaliknya dari menganjurkan kehidupan yang menarik diri dan hidup membiara dan selibat; berubah menjadi kehidupan yang melibatkan diri dalam beragam bentuk aktivitas: keluarga, tempat kerja, gereja dan masyarakat. Spiritualitas pribadi dan komunitas harus diseimbangkan. ${ }^{23}$ Dengan demikian, spiritualitas kristiani harus dilihat dari kehidupan Yesus: lahir, tumbuh, berelasi dengan banyak orang, kematian dan kebangkitan.

\footnotetext{
${ }^{20}$ J. Knox Chamblin, Paulus Dan Diri: Ajaran Rasuli Bagi Keutuhan Pribadi, ed. Jeane Ch. Obadja (Surabaya: Momentum, 2020). 4-5. ${ }^{21}$ M. Robert Mulholland Jr., Panggilan Ziarah. Bagaimana Mengembangkan Spiritualitas Yang Holistik. (Yogyakarta: Penerbit ANDI, 2002). 6. ${ }^{22}$ Eka Dharmaputera, "Agama Dan Spiritualitas: Suatu Perspektif Pengantar," PENUNTUN III, No. 12 Jurnal Teologi dan Pelayanan (Jakarta: GKI Jabar, Juli 1997), 390.
}

Perjalanan kehidupan/spiritualitas Kristen merupakan komitmen yang disadari dan terusmenerus terhadap proses pertumbuhan seumur hidup menuju keutuhan dalam Kristus, "bertumbuh dalam segala hal ke arah Kristus yang adalah kepala" (Efesus 4:15), hingga kita "mencapai" kedewasaan penuh dan tingkat pertumbuhan yang sesuai dengan kepenuhan Kristus (Efesus 4:13). Demi kegenapan tujuan ("penuh", Yun. "toleios", sempurna atau utuh) inilah, Allah hadir dan aktif di setiap momen dalam hidup orang percaya. Kebenaran ini menjadi dasar pembentukan komunitas Kristen yang mempratikkan kebenaran Allah dalam keseharian di bidang apapun. Mulholland menyebutnya dengan istilah "spiritualitas holistik". ${ }^{24}$ Jadi spiritualitas kelompok dan sosial dalam praktik hidup merupakan bagian yang esensial dari pembentukan spritualitas kristiani yang holistik.

Penulis sependapat dengan pandangan kedua yang menekankan keseimbangan dan keutuhan hubungan atas-bawah. Selain itu, bila dikaitkan dengan diri anak, proses spiritualitas yang dimaksud sesuai dengan kebutuhan anak di tahap perkembangannya, dimana anak lebih mudah menerima keteladanan daripada keterangan atau penjelasan. Yesus sebagai anak di bawah hukum Taurat (Lukas 2: 40, 52) dibesarkan dalam spiritualitas Yahudi kedua orang tuanya yang sangat mungkin juga mewarisi tradisi spiritualitas Israel dalam konteks keluarga di masa eksodus.

Tradisi spiritualitas Israel yang bukan sekadar bermula dari konsep, melainkan dari pengalaman keseharian menjalankan ibadah
23 Paul Hidayat, Hidup Dalam Ritme Allah, ed. James C. Pantou (Jakarta, 2005), 34 https://www.ppa.or.id.; Nicholas P Wolterstorff, Mendidik Untuk Kehidupan (Surabaya:

Momentum, 2020).

24 R. Paul Stevens, Down to Earth. Spiritualitas Yang Membumi, ed. Nicholas Kurniawan, Kesatu. (Malang: Literatur SAAT, 2009). Jr., Panggilan Ziarah. Bagaimana Mengembangkan Spiritualitas Yang Holistik, 6o-7o. 
atau ketaatan pada perintah Tuhan seperti yang dimaksud dalam Ulangan 6:4-9. Minimal ada tiga kebenaran penting tentang spiritualitas. Pertama, formasi spiritualitas anak berawal dari pengalaman bersama orang tuanya, "supaya seumur hidupmu engkau dan anak cucumu takut akan TUHAN" (ayat 2) kemudian "haruslah engkau mengajarkannya, membicarakannya, mengikatnya, menuliskannya" (ayat 6-9). Ayat 6-9 ini menegaskan bahwa spiritualitas anak merupakan buah keteladanan dari spiritualitas orang tuanya. Prinsipnya, apa yang orang tua lakukan akan menjadi pola selanjutnya yang akan dilakukan anak. Like father like son - like mother like daughter, sebagaimana orang tuanya, begitu pulalah perilaku anak-anaknya. Orang tua selaku pendidik utama tidak perlu mengatakan banyak hal, lakukan saja maka anak akan menirukannya, tanpa anak harus mengerti mengapa hal-hal tersebut dilakukan. James Gardner menegaskan kebenaran ini bahwa dari orang tua anak mewarisi nilai, harapan terkait masa depan, dan konsep dasar berkenaan dengan hidup. ${ }^{25}$ Penting bagi orang tua memastikan dirinya telah melakukan tugas dan bagiannya dengan benar.

Spiritualitas anak akan dibangun bersama pengalaman itu sendiri. Hal yang sama seharusnya juga menjadi pola pembelajaran guru kepada anak-anak melalui setiap penugasan yang diberikan. Beri kesempatan anak berpengalaman dengan Tuhan. Crapps mengatakan, "hal yang paling penting bagi pertumbuhan keagamaan anak-anak adalah mutu pengalaman yang berlangsung lama dengan orang-orang dewasa yang berarti dan penting bagi mereka”. Lebih lanjut Crapps juga menegaskan "dari lingkungan yang penuh kasih dan sayang yang diciptakan orang tua, lahirlah pengalaman keagamaan yang mendalam". ${ }^{26}$

\footnotetext{
25 Mardiharto Mardiharto, "Pola Asuh Pendidikan Kerohanian Pada Anak," PASCA : Jurnal Teologi dan Pendidikan Agama Kristen 15, no. 1 (2019): 23-27.
}

Kedua, meskipun spiritualitas anak berbasis pengalaman, namun formasi itu sendiri harus dilakukan dengan sadar/sengaja. Dalam konteks awal yang berlaku sampai hari ini, "mengajarkan" (ayat 2), merupakan perintah pribadi kepada orang tua/pemimpin yang harus ditaati. Sama seperti Tuhan mempunyai alasan mengapa syema yitsrael harus diajarkan dan disampaikan berulang kepada bangsa Israel yang berada di tengah-tengah bangsa asing; demikian jugalah orang tua/guru selaku pendidik bagi anak di tengah tantangan zaman ini. Kesadaran menjalankan perintah ini mewujud melalui pengalaman dalam struktur komunikasi bersama keluarga. ${ }^{27}$ Dalam konteks pendidikan hari ini, kebenaran ini dilakukan melalui kurikulum yang bertujuan membangun pengalaman spiritualitas tentang Allah, yang mewujud melalui kebaikan kepada sesama dan lingkungan di sekitar anak.

Ketiga, formasi spiritualitas anak merupakan proses. Selama 430 tahun Israel hidup dalam bayang-bayang spiritualitas Mesir, sementara mereka sendiri belum mempunyai pengajaran yang tersimtematiskan. Wajar perjalanan Israel menuju Kanaan penuh gejolak yang mencerminkan romantisme budaya Mesir. Israel tidak mudah memercayai bahwa bukan hanya "TUHAN itu Allah kita" tapi juga "TUHAN itu esa", sebab spiritualitas Mesir bertumpu pada banyak dewa. Di sinilah kepentingan mengajarkan syema yitsrael bukan sebagai konsep, tetapi sebagai pengalaman pribadi orang tua dan anak dengan cara "mengajarkan berulang-ulang..." (ayat 6-9. Ibr. Shanan, mempertajam, mengasah) melalui beragam kesempatan. Sebab merubah spiritualitas yang tertanam sejak lama bukan hal yang mudah. 28

Proses juga menegaskan bahwa menjadi baik

26 Crapps, Perkembangan Keperibadian \& Keagamaan, 13-14.

${ }_{27}$ Mardiharto, "Pola Asuh Pendidikan Kerohanian Pada Anak", 24.

28 Andrew Hill; John Walton, Survei Perjanjian

Lama (Malang: Gandum Mas, 1996). 
dan konsisten membutuhkan waktu dan keteladanan orang tua/pendidik. Proses spiritualitas orang tua akan menentukan berjalannya proses formasi spiritualitas anak. Dalam konteks pendidikan, guru sebagai pendidik utama perlu mengenal keunikan pribadi anak dengan beragam persoalannya. Tanpa mengenal, semua kegiatan akan sia-sia saja. Misalnya, beberapa sekolah Kristen di level pendidikan awal berani menetapkan target "anak menerima Yesus sebagai juruselamat pribadi”. Apa indikatornya bahwa anak telah menerima Yesus sebagai Juruselamat? Bila keselamatan bersifat personal, tidakkah penetapan target merupakan pengingkaran proses? Mungkinkah penetapan target menjadi bagian dari problematika pendidikan formal yang seringkali terjebak pada persoalan memenuhi kewajiban dan melupakan hakekat dari pendidikan itu sendiri?29

Kekristenan adalah proses pengalaman bersama Tuhan. Maka capaian pembelajaran adalah proses itu sendiri; sementara menerima Yesus sebagai Juruselamat adalah bagian dari proses yang tidak perlu seolah dipaksakan hanya berdasarkan pengakuan personal anak, yang dalam proses itu sendiri belum sepenuhnya memahami. Sebaiknya beri kesempatan anak-anak sedini mungkin mengalami dan merasakan undangan Yesus secara pribadi seperti tertulis, "Biarkan anakanak itu datang kepada-Ku, jangan menghalang-halangi mereka" (Markus 10:14).

Menurut Stevens, spiritualitas Yakub bukan hanya dibangun dari pengalaman ketika berjumpa dengan Allah dan menamai tempat itu dengan "Betel", tetapi sepanjang pergumulan dia sebagai pribadi; termasuk pelariannya dari Esau kakaknya sampai konflik

\footnotetext{
29 Mardiharto Mardiharto, "Pembangunan Sumber Daya Manusia Melalui Bidang Pendidikan Agama Kristen," PASCA : Jurnal Teologi dan Pendidikan Agama Kristen 15 (2019): 28-32.

3o Stevens, Down to Earth. Spiritualitas Yang Membumi, 13-14.
}

dengan Laban. ${ }^{30}$ Sama seperti itu, maka orang tua dan guru sebagai pendidik hanyalah menjadi perantara perjumpaan mereka dengan Tuhan. Dengan demikian anak mengalami pembentukan spiritualitas yang alami dan bersengaja.

\section{Formasi Spiritualitas Anak dalam Pendidikan}

Apa yang menjadi tujuan dan fokus utama dalam pelaksanaan pendidikan? Jawaban pertanyaan ini menjadi dasar memahami formasi spiritualitas anak dalam hubungannya dengan pendidikan, seperti yang disebutkan Amsal 22:6, "Didiklah orangmuda menurut jalan yang patut baginya, maka pada masa tuanya ia tidak akan menyimpang dari pada jalan itu". Penulis Amsal menegaskan peran penting pendidikan bagi pembentukan spiritualitas anak sejak dini. Kata "jalan" (Ibr. Derek) mengacu pada pengajaran moral berdasarkan tradisi oral yang disampaikan orang tua (selaku pendidik) dalam relasinya dengan anak. Proses mendidik sendiri berlangsung sepanjang hayat yang pemenuhannya disesuaikan dengan kebutuhan unik anak di setiap tahapan perkembangannya.

Pemahaman ini selaras dengan upaya pencapaian tujuan pendidikan nasional yang berfokus pada manusianya, "mengembangkan potensi peserta didik agar menjadi manusia yang beriman dan bertakwa kepada Tuhan Yang Maha Esa, berakhlak mulia, sehat, berilmu, cakap, kreatif, mandiri, dan menjadi warga negara yang demokratis serta bertanggung jawab", 31 yang dalam pelaksanaannya membutuhkan guru sebagai pendidik utama. ${ }^{2}$ Kesanggupan manusia mengaktualisasikan dirinya secara positif bagi kehidupan merupakan wujud pengembangan diri manusia

${ }^{31}$ Kemendikbud, "Undang-Undang Nomor 20 Tahun 2003 Tentang Sistem Pendidikan Nasional," last modified 2003, Nasional.

32 Kemendikbud, "Undang-Undang Nomor 14

Tahun 2005 Tentang Guru Dan Dosen, Bab II Pasal VI," Kemendikbud. 
yang dicapai melalui pendidikan.33 Groome menegaskan bahwa segala daya upaya dalam pendidikan harus dilakukan bersengaja, sistematis dan berkelanjutan demi pencapaian tujuan yang ditetapkan. 34 Jadi pendidikan merupakan wahana untuk mengembangkan semua potensi manusia di dalam dan bagi kehidupan. Berdasarkan pemahaman di atas dan dalam hubungannya dengan tujuan pendidikan nasional, maka (bagi penulis) hubungan formasi spiritualitas anak dan pendidikan dapat dilihat melalui 3 (tiga) hal berikut: konsep, kurikulum dan model (praktik).

Pertama, membangun konsep pendidikan spiritualitas melalui tindakan yang bermoral. Menurut Lickona perilaku moral, karakter dan kepribadian anak berwujud pada perbuatan sehari-hari. Agar anak dapat berperilaku baik, dibutuhkan standar bagi model perilaku yang langsung dapat anak tiru. Kehadiran dan peran orang terdekat (keluarga dan guru) pasti memengaruhi bentukan spritualitas anak. Bahkan terkadang sebelum lahirpun, orang tua sudah menanamkan nilai-nilai dengan cara memengaruhi mereka dengan beragam cara. 35 Kedalaman relasi anak dengan orang terdekat menjadi pengetahuan awal yang menentukan perilaku sehari-hari. Pola berpikir, bersikap dan bertindak anak usia dini terbatas pada apa yang mereka: lihat, dengar, dan alami, sehingga pembentukan dan pemahaman awal terhadap moralitas menjadi hal penting dan esensial bagi tahapan/pengembangan moral mereka.

Tahapan-tahapan perkembangan moral anak dapat dilihat dari berbagai tinjauan teori, khususnya yang berhubungan dengan tinjauan

33 Prayitno, Dasar Dan Teori Praksis Pendidikan (Jakarta: Grasindo, 2009), 25; Jr., Panggilan Ziarah. Bagaimana Mengembangkan Spiritualitas Yang Holistik. Wolterstorff, Mendidik Untuk Kehidupan, 5.

34 Thomas H. Groome, Christian Religious

Education (Jakarta: BPK Gunung Mulia, 2010), 29. psikologi perkembangan anak. Membangun atau mendidik moral anak sampai pada tataran perilaku memerlukan tiga proses pembinaan yang berkelanjutan, yaitu moral knowing, moral feeling, dan moral action. ${ }^{6}$ Ketiganya harus dikembangkan secara terpadu dan seimbang melalui pembelajaran. Dengan demikian potensi anak dapat berkembang secara optimal, baik pada aspek kecerdasan intelektual, maupun perilaku dalam relasi dengan orang lain.

Moral knowing menegaskan bahwa perkembangan moral anak diawali oleh pengetahuan tentang moral yang dibiasakan melalui pengalaman. Masa anak-anak merupakan periode yang sangat dinamis secara psikologis bagi perkembangan religius. Anakanak mempunyai kemampuan meniru yang luar biasa perilaku orang dewasa di sekitarnya. Orang-orang dewasa, keluarga khususnya dan lembaga-lembaga keagamaan perlu memberikan teladan yang benar dan konsisten. Pengalaman keagamaan atau spiritualitas yang mendalam dapat menjadi cara untuk menyiapkan anak melanjutkan peziarahan di masa dewasanya. 37

Pengetahuan yang disampaikan berulang melalui pengalaman akan menjadi dasar bagi anak memahami 'aturan' berperilaku, baik dalam lingkup keluarga maupun masyarakat. Pengetahuan moral dapat dimaksimalkan melalui pengalaman panca indra anak. Dalam hal ini pendidik perlu dengan sengaja memberikan contoh visual sederhana melalui video kepada anak tentang kebaikan di tengah keluarga atau masyarakat. Sebisa mungkin contoh yang disampaikan bukan dalam bentuk persoalan, sebab anak membutuhkan modeling,

35 Robert Coles, Menumbuhkan Kecerdasan Moral Pada Anak (Jakarta: Gramedia, 2000), 75.

${ }^{36}$ Hidayat, Metode Pengembangan Moral Dan Nilai-Nilai Agama, 10. .

37 Crapps, Perkembangan Keperibadian \& Keagamaan, 22. 
konsistensi dan keseragaman.

kejujuran, menyampaikan

Misalnya salam, mengucapkan terimakasih, mau berteman, menolong teman, membuang sampah pada tempatnya, mendengar nasihat orang tua dan lain-lain. Prinsipnya pengetahuan moral anak dibangun melalui pengalaman kebaikan yang diteladankan dengan cara sederhana tapi konsisten.

Kesederhanaan teladan akan menolong anak mudah menirukan (moral action). Dalam jangka panjang kebaikan tersebut akan menjadi ciri khas atau karakter mereka. Pada tahap ini, pembiasaan menuntun anak menemukan dan membedakan sikap moral yang baik dan tidak. Tanggapan atas perilaku anak diperlukan sebagai konfirmasi mana yang benar dan atau salah. Tanggapan juga bertujuan melatih ketrampilan anak sedini mungkin untuk menghubungkan (moral feeling) pilihan perilaku dan sikap hati mereka tentang yang "baik" dan "tidak baik" yang bersesuaian dengan moral knowing yang dibiasakan.

Kedua, kurikulum dipahami sebagai perangkat rencana pendidikan formal yang teratur dan yang didokumentasikan dengan tujuan mencapai sasaran yang sudah ditentukan. ${ }^{8}$ Bagaimana mencapai tujuan kurikulum di masa pandemi? Bukankah anak usia dini yang membutuhkan pembelajaran langsung menjadi kelompok siswa yang paling terdampak di masa pandemi? Guru perlu menyiapkan perubahan kurikulum atau setidaknya ada implikasi khusus yang disiapkan dengan berpedoman pada nilai-nilai kristiani yang mampu diimplementasikan secara daring. Secara lebih khusus, implikasi yang dimaksud adalah memikirkan media pengganti atau 'menciptakan' keadaan tertentu melalui penugasan yang sekiranya menolong anak punya pengalaman spiritual mendalam,

${ }^{38}$ Harro van Brummulen, Batu Loncatan Kurikulum Berdasarkan Alkitab (Tangerang: UPH Press, 2008), 20. yang melibatkan orang terdekat. Lickona memberikan saran agar kurikulum dirancang untuk mengajarkan nilai-nilai moralitas (kejujuran, integritas, rasa hormat, tanggung jawab). Para pendidik dapat memberikan penugasan kepada anak dengan cara sederhana agar mereka mengembangkan rasa tanggung jawab di rumah. Mendorong tenggang rasa dan kepekaan etis melalui pengamatan pertumbuhan benih dan mencatatnya. Memotivasi anak-anak untuk menemukan ide bagaimana mewujudkan kepedulian kepada sesama di masa pandemi. Memberikan ide menulis cerita pengalaman belajar selama daring atau membuat coretan-coretan seolah poster tentang pentingnya pemakaian masker.

Sementara itu, masa pandemi yang tidak menentu ditambah dengan pembiasaan baru pendidik dan peserta didik menggunakan platform digital, maka pengembangan kurikulum yang berbasis pendidikan jarak jauh harus lebih memerhatikan aspek: flexibility, compassion, dan engangement. 39 Flexibility artinya pendidikan tidak boleh memaksakan ekspektasi pada realita sebelum masa pandemi. Ketidaknormalan kondisi perlu dihadapi dengan strategi yang juga tidak normal atau di luar kebiasaan rutin. Pendidik perlu memberi ruang penyesuaian diri kepada semua pihak yang terlibat proses pendidikan untuk dapat beradaptasi dengan cara-cara baru yang serba digital. Capaian pembelajaran sesungguhnya adalah proses memberi pengalaman moralitas kepada anak melalui peran orang tua. Bukan kesanggupan anak melakukan kebaikan. Berikan kesempatan anak menemukan dan mewujudkan model spiritualitasnya berdasarkan ketedalanan yang orang tua/guru sampaikan.

Compassion artinya pendidik harus terus memastikan kondisi mental anak, baik sebelum dan saat proses pembelajaran berlangsung baik

39 Anonymous, "Realita Pendidikan Indonesia Di Masa Pandemi," UII. 
daring maupun luring. Sapaan dan bercanda ringan akan menenangkan anak. Dalam keadaan normal, emosi anak umumnya tidak stabil sebab mereka baru pada tahap keluar dari zona nyaman menuju lingkungan yang lebih luas.40 Di sisi lain, anak pada masa pandemi kehilangan kebutuhan pertemanan langsung dengan teman-teman sebaya. Kemampuan motoriknya juga kurang terlatih. Pendekatan kurikulum yang penuh compassion diperlukan sehingga terjalin ikatan emosi antara pendidik dan anak, yang akan 'mempermudah' pembelajaran. Dari sisi anak, pengalaman dipahami dan diterima menjadi dasar kedalaman relasi, sekaligus terbangunnya moral feeling dalam proses berspiritualitas.

Engagement artinya dengan mental yang baik akan berdampak pada rasa antusiasme dan sinergitas yang baik antara pendidik dan peserta didik. Tahap ini merupakan hasil dari dua tahap sebelumnya. Pendidik perlu berkreasi agar selama proses pembelajaran, tetap terjalin relasi yang baik dengan peserta didik. ${ }^{41}$ Tidak mudah tetapi juga bukan hal yang tidak mungkin dilakukan. Dalam situasi normal saja, seorang pendidik perlu memenangkan hati anak untuk mendengar cerita/materi yang disampaikan. Apalagi dalam situasi serba berjarak. Pendidik bisa terjebak sekadar menyampaikan materi. Fokus pada upaya selesainya materi tapi lupa membangun hubungan dengan peserta didik. Kegagalan pendidik membangun relasi merupakan kegagalan membangun spiritualitas yang positif bagi anak.

Pendidik perlu belajar mengkombinasikan pemakaian alat peraga berupa boneka, video audio, penggunaan suara yang berbeda, drama

40 Hurlock, Psikologi Perkembangan: Suatu Pendekatan Sepanjang Rentang Kehidupan, 114. ${ }_{41}$ Jawahir Gustav Rizal, "Realita Pendidikan Indonesia Di Masa Pandemi," KOMPAS. 42 Rusman, Model-Model Pembelajaran. Mengembangkan Profesionalisme Guru, Kedua. (Jakarta: RajaGrafindo Persada, 2016), 188; T.G. singkat, story telling dan lain-lain yang bertujuan sebagai penyampai atau penguat pesan spiritualitas kepada anak. Jangan lupa juga untuk mendorong anak melakukannya bersama orang tua dengan cara yang paling memungkinkan bagi mereka. Itu sebabnya pelaksanaan kolaborasi tiga sifat kurikulum ini perlu ditunjang dengan pemilihan model pembelajaran yang sesuai dengan konteksnya; sekaligus faktor ketiga yang menghubungkan formasi spiritualitas dan pendidikan.

\section{Model Pembelajaran Kontekstual \& Peran Pendidik}

Pembelajaran kontekstual sebagai sebuah model bersesuaian dengan karakteristik pengembangan spiritualitas anak. Sebab model ini berfokus pada keunikan anak dan situasi yang dihadapinya. Melalui model ini, pembelajaran luring maupun daring bukan hanya akan menarik, tetapi juga diupayakan dekat dan sesuai kebutuhan anak atau konteksnya. Makna "konteks" dipahami sebagai benda atau kejadian nyata, model atau representasi dari konsep yang akan dipelajari, sesuatu yang dibayangkan peserta didik atau yang telah diskemakan pendidik.42 Model pembelajaran kontekstual juga membantu pendidik mengaitkan materi yang diajarkan dengan situasi dunia nyata anak, serta mendorong anak untuk membuat hubungan antara pengetahuan yang dimilikinya dengan penerapan sehari-hari sebagai wujud spiritualitasnya. 43

Dalam penerapannya, pembelajaran kontekstual mempunyai tujuh prinsip pembelajaran yang implementasinya dapat disesuaikan dengan kebutuhan pengembangan spiritualitas anak. Pertama, konstruktif. Seperti yang disinggung di atas, prinsip ini

Ratumanan, Inovasi Pembelajaran.

Mengembangkan Kompetensi Peserta Didik

Secara Optimal (Yogyakarta: Ombak, 2015), 73

https://www.penernitombak.com.

43 Hidayat, Metode Pengembangan Moral Dan Nilai-Nilai Agama, 26. 
membantu para pendidik menemukan makna dalam proses pembelajaran dengan cara mengaitkan apa yang dipelajari dengan apa yang kemudian dipraktikkan. Pendidik didorong untuk memfasilitasi anak menemukan makna pembelajaran spiritualitas melalui kegiatan rutin yang secara konsisten dilakukan.44 Misalnya Materi pembelajaran tentang kasih kepada Tuhan dapat diwujudkan melalui bentuk-bentuk ibadah (vertikal) dan perbuatan baik kepada sesama dan alam (horizontal). Pendidik perlu memastikan bahwa anak bukan hanya melaksanakan tugas tetapi juga belajar memahami alasan atau mengapa pembelajaran itu dilakukan. Anak akan terlatih membangun makna (konstruktif) dari semua pengalaman yang di dapat selama pembelajaran. Pendidik memberikan kesempatan pada anak memilih cara untuk mengekpresikan pengalamannya, baik dalam hubungannya dengan Tuhan maupun sesama.

Kedua, menemukan sendiri (inquiry). Berkaitan dengan prinsip sebelumnya, pendidik mengijinkan anak menceritakan kembali pengalaman riil spiritualias yang ia 'temukan' ketika melakukan tugas. Pendidik bisa mengajukan pertanyaan, meminta mereka bercerita tentang pengalaman selama mengerjakan tugas atau memberikan kesempatan anak mengekspresikan perasaan syukur mereka melalui pujian, puisi atau gambar. Fokusnya pada keberanian menceritakan pengalamannya secara khas. Bukan pada ketepatan makna. Prinsip ini melatih anak punya kedalaman makna atas pengalaman spiritualitasnya. Bukan sekadar aktivitas tapi apa yang didapatkan/dipelajari.

Ketiga, bertanya (questioning). Prinsip bertanya memberi kesempatan pendidik menggali informasi sebanyak mungkin dan berfokus pada anak melalui pertanyaan yang disampaikan.45 Pendidik juga perlu menitipkan pertanyaan di setiap tugas yang diberikan, "apa yang kamu pelajari tentang Tuhan dan orang lain?" atau "hal baik apa yang kamu ingin lakukan setelah ini?" Ragam pertanyaan ini melatih anak sedini mungkin mengaitkan keseharian dengan realitas yang lebih besar dari dirinya; sekaligus berusaha menemukan implementasi terbaik berupa tindakan positif bagi orang lain. Dengan demikian anak belajar memercayai ada Tuhan yang berdaulat dalam hidupnya. Di sisi lain, ketika pendidik mengajukan pertanyaan, anak juga merasa dilibatkan bahkan diajak turut menentukan (elaborasi) jenis tindakan atau bentuk-bentuk spiritualitas yang sesuai dengan passionnya. Pendidik juga bisa mengarahkan berdasarkan penggalian informasi awal tentang karakter anak. Prinsip ini sekaligus menolong guru mengetahui suasana hati anak selama pembelajaran. Memahami bahwa tanggapan pendidik turut memengaruhi proses spiritualitas anak, maka pendidik perlu memberikan tanggapan yang tepat melalui komentar atau catatan mendukung keyakinan anak.

Keempat, komunitas belajar. Prinsip ini bertujuan melatih kolaborasi kecerdasan spiritual dan sosial anak melalui kesempatan saling berbagi cerita dengan teman sebaya melalui aplikasi pembelajaran. Pendidik perlu memfasilitasi anak untuk bersedia menceritakan pengalaman selama mengerjakan tugas, sekaligus sebisa mungkin menemukan pelajaran berharga tentang Tuhan dan sesama yang bisa mereka bagikan dengan cara apapun melalui komunitas.

Kelima, pendidik adalah model terbaik bagi anak. Apa yang dilakukan pendidik akan menjadi pola bagi anak. Jadi pemodelan berfokus pada upaya pendidik memberikan keteladanan melalui cerita, video atau praktik langsung supaya anak mengerti capaian
44 Ratumanan, Inovasi Pembelajaran. Mengembangkan Kompetensi Peserta Didik Secara Optimal, 72.
45 Rusman, Model-Model Pembelajaran.

Mengembangkan Profesionalisme Guru, 195. 
pembelajaran spiritualitas yang diharapkan. Pemodelan juga bisa berlaku dari sesama murid melalui sharing sebagai komunitas (prinsip keempat). Pendidik bisa memberikan contoh kata-kata yang baik; juga bagaimana melakukan kebaikan dengan cara yang benar. Misalnya, pendidik menjelaskan pentingnya doa dengan cara mencontohkan bagaimana berdoa. Sekali lagi yang terpenting di sini bukan apa yang anak bisa lakukan, tetapi memberi kesempatan secara terarah dan sistematik pada anak berproses mengalami spiritualitasnya. Bahkan sangat disarankan menetapkan jadwal untuk menanamkan pembiasaan baik bagi anak dalam melakukan hal-hal dasar yang perlu di awal tahapannya (basic life skill).

Keenam, refleksi dimengerti sebagai respons sederhana dari anak apapun bentuknya. Anak bisa mengulang penjelasan tugas seperti apa yang diminta gurunya; atau bisa menceritakan ulang kegiatan yang dilakukan. Misalnya, bila kegiatan yang dimaksud adalah doa, anak bisa menceritakan apa, bagaimana dan mengapa berdoa? Refleksi sudah dilatihkan ketika anak diberikan kesempatan berbagi pengalaman pribadi ataupun melalui komunitas kelas daring. Konfirmasi pendidik tentang Tuhan dan sesama sebagai satu kesatuan diperlukan sebagai tanggapan atas perbuatan baik yang mereka lakukan di setiap tugas dan kehidupan. Hal ini akan menolong anak membangun keyakinannya bahwa Tuhan ada dan berkenan atas setiap perbuatan baik yang mereka lakukan, sekecil apapun itu. Kolaborasi keenam prinsip diatas dapat diwujudkan melalui variasi kegiatan atau pemberian tugas secara daring yang menunjang tujuan pembelajaran. 46 Misalnya bermain peran, menceritakan lingkungan rumah, demostrasi ketrampilan, melakukan wawancara dengan keluarga, proyek ketaatan dengan cara melakukan

\footnotetext{
46 Hidayat, Metode Pengembangan Moral Dan Nilai-Nilai Agama, 28.

47 Ratumanan, Inovasi Pembelajaran.

Mengembangkan Kompetensi Peserta Didik Secara Optimal, 90.
}

kebaikan yang belum pernah dilakukan, mengerjakan tugas-tugas rumah, menghafal ayat, menari, baca puisi, bernyanyi sesuai tema dan lain-lain. Butuh kesabaran membuka wawasan dan memberi semangat agar anak mengerjakan tugas pengembangan spritualitasnya. Sebaiknya pendidik juga perlu belajar mengetahui dan memahami teknikteknik pendekatan atau komunikasi dalam rangka membentuk tingkah laku atau spiritualitas anak.

Misalnya teknik yang bertujuan: memahami, mengabaikan, mengalihkan perhatian, keteladanan, hadiah, perjanjian, membentuk, mengubah lingkungan rumah, memuji, mengajak, menantang, menggunakan akibat yang wajar dan alamiah, sugerti, meminta, peringatan, kerutinan dan kebiasaan, menghadapkan suatu problem, menyelesaikan konflik, menentukan batas-batas aturan, memberi hukuman, penentuan waktu dan durasi hukuman, menggunakan pengendalian secara fisik.

Ketujuh, penilaian unjuk kerja secara otentik. Prinsip ini merangkum seluruh implementasi semua prinsip yang dilakukan anak ketika mengerjakan tugas kelas daring ke dalam catatan penilaian pendidik yang apa adanya. 47 Penilaian autentik membuka ruang bagi anak mendemonstrasikan kemampuannya untuk menjelaskan tugas-tugas pembelajaran, mencari solusi, atau mengekspresikan apa yang dipahami dengan cara mensimulasikan situasi yang dapat ditemui di dalam dunia nyata di luar lingkungan sekolah. Penilaian ini juga dapat menjelaskan bagaimana peserta didik menyelesaikan tugas yang diberikan guru dengan kemungkinan lebih dari satu solusi. 48 Beberapa metode penilaian bisa dipilih sesuai dengan kebutuhan: penilaian unjuk kerja, portofolio, proyek sosial dan pencatatan model

\footnotetext{
48 Kadek Agus Prama \& Dewa Bagus, Merancang Penilaian Otentik (Jembrana: Media Educations, 2019), 10.
} 
buku harian. Kumpulan catatan penilaian autentik dapat menjadi penyedia informasi dan kendali mutu sejauhmana semua komponen pendidikan berjalan sesuai fungsinya.49 Jadi penilaiannya berlaku dua arah, pendidik dan peserta didik, yang berujung pada upaya perbaikan dua belah pihak.

Prinsipnya, apapun pilihan metodenya, penilaian harus berfokus pada proses perubahan spiritualitas yang anak lakukan di dalam keunikannya. Apa yang tampak tidak selalu yang sebenarnya. Wajar bila seorang pendidik tetap harus meluangkan waktunya untuk melakukan observasi dan wawancara pribadi secara daring (personal) kepada setiap anak didik. Setidaknya penilaian autentik menyediakan catatan tentang bagaimana proses spiritualitas tersebut tertanam dan mulai bertumbuh dalam diri anak.

Dengan kata lain, peran pendidik dalam pelaksanaan setiap prinsip model pembelajaran kontekstual sangat penting dan menentukan. Keunikan cara atau kekhasan pendekatan bagi anak hanya mungkin dilakukan oleh pendidik yang dekat dan mampu membangun persahabatan dengan anak. Terlebih seperti yang sudah disinggung bahwa spiritualitas anak sangat dipengaruhi pribadi terdekat. Bagaimanapun pergumulan pendidik, anak hanya fokus pada pribadi pendidik yang berkata-kata dan bersikap di depan mereka. Apalagi pembelajaran melalui aplikasi daring, makin menjadikan anak-anak sangat fokus dengan kedirian pendidik yang mereka lihat di layar. Pendidik harus belajar menjadi model, mentor, dan coach bagi pembentukan spiritualitas anak didik.

\section{Kesimpulan}

Dari pembahasan di atas, dapat disimpulkan bahwa pendidikan Kristiani sangat penting sebagai sarana pembentukan spiritualitas generasi millenial saat ini. Spiritualitas merupakan anugerah Allah dan melalui pendidikan diarahkan kepada manusia khususnya generasi millenial agar mereka dapat menghayati serta bertanggungjawab dihadapan Tuhan dalam setiap aspek kehidupannya. Dengan kata lain, spiritualitas Kristiani membangun relasi dengan Allah, yang mampu masuk ke dalam setiap aspek kehidupan manusia. Generasi millenial sudah mampu untuk mengerti serta memahami kebutuhan mereka dalam hidup sehari-hari, akan tetapi perlu untuk mendalami kehidupan spiritual agar mereka mampu untuk terus berkembang dan juga dapat menghidupi spiritualitas mereka di dalam Kristus. Disinilah pendidikan Kristiani berperan untuk membentuk spiritualitas mereka.

Adapun pembentukan Spiritualitas melalui pendidikan Kristiani dilakukan dalam konteks sekolah, gereja dan juga keluarga. Ketiganya punya model masing-masing, tetapi penerapan dasar pendidikannya sama-sama berbasis kepada Firman Tuhan yang dinyatakan dalam Alkitab melalui pengenalan akan Kristus Yesus serta bimbingan dari Roh Kudus. Dalam praksisnya, karakteristik pendidikan Kristiani sebagai sarana pembentukan spiritualitas bersifat fleksibel, dalam membangun relasi kepada sesama serta bercorak seperti sahabat/ hospitality yang mampu untuk membimbing generasi millenial sesuai dengan konteks pemikiran atau intelektualitas mereka tetapi tidak meninggalkan dasar-dasar Firman Tuhan. Selanjutnya, hasil dari penelitian ini kiranya dapat berkontribusi dalam ilmu teologi praktika dalam hal ini Pendidikan Kristiani mengenai pembentukan spiritualitas bagi generasi millenial. Secara praktis, penelitian ini diharapkan diterapkan serta dapat meningkatkan kehidupan spiritualitas orang percaya melalui pendidikan Kristiani dalam hal ini generasi millenial dalam lingkup sekolah, 
gereja, dan keluarga. Kemudian terkait rekomendasi penelitian, perlu mengadakan penelitian lanjutan yang membahas secara spesifik atau mendetail mengenai karakteristik atau model pembentukan spiritualitas bagi generasi millenial melalui pendidikan Kristiani secara khusus di sekolah, di gereja, dan juga lingkup keluarga.

Pendidikan merupakan upaya sadar dalam membina dan mengembangkan harkat serta martabat anak sebagai manusia secara utuh dan menyeluruh di semua aspek perkembangannya. Tujuan pendidikan ini selaras dengan makna spiritualitas berdasarkan Alkitab yang mencakup kedirian manusia sebagai pribadi yang diciptakan Allah, baik tubuh jasmani maupun rohaninya. Artinya, spiritualitas dimaknai bukan hanya sebagai sikap dalam ibadah, tetapi lebih besar dan mendasar yaitu pengalaman bersama Tuhan yang kebenarannya tercermin melalui integritas hidup yang bermoral dalam relasi dengan sesama dan semesta.

Di sisi lain membangun spiritualitas anak merupakan perjalanan sepanjang hayat yang ditentukan melalui keteladanan orang dewasa. Membangun spiritualitas tidak bisa dipahami semudah menemukan dan mengatur puzzle dalam kotak permainan yang bentuk dan ukurannya sudah ditentukan. Tidak demikian halnya dengan anak. Mereka bukanlah orang dewasa dengan tubuh kecilnya, yang seolah harus mengerti dan mengikuti apa yang diajarkan. Maka mempertimbangkan hadirnya model pembelajaran yang sesuai di masa pandemi menjadi sesuatu yang penting dalam rangka membangun formasi spiritualitas anak.

Melalui beberapa prinsip yang dipaparkan penulis, model pembelajaran kontekstual dapat dipertimbangkan sebagai alternatif bagi pendidik untuk melakukan modeling, pendampingan, pelatihan dan penilaian atas tindakan baik (moralitas) yang diupayakan anak dengan berbasis pada pengalaman, baik secara pribadi maupun komunitas (via daring).
Dengan demikian formasi spiritualitas anak di masa pandemi, adalah sesuatu yang masih sangat mungkin untuk dilakukan melalui model pembelajaran terpilih (kontekstual).

Pada akhirnya, pembelajaran jarak jauh dengan segala tantangannya menuntut kehadiran dan peran guru, bukan hanya sebagai pendidik yang memberikan materi pembelajaran, tetapi juga sebagai gembala bagi anak yang menyediakan "rumput hijau" dan "air tenang" yang menyejukkan jiwanya. Kehadiran dan peran pendidik yang terlihat dan maksimal bagi anak, akan merepresentasikan kehadiran Tuhan yang tidak terlihat namun dipercayai ada dan berkarya dalam kehidupan anak.

\section{Kontibusi Penelitian:}

Hasil penelitian ini memberikan kontribusi pada Ilmu Teologi (operatif), yaitu mengenai konsep dan praktik formasi spiritualitas anak di masa pandemi. Secara praktis, penelitian ini juga berkontribusi pada upaya meningkatkan layanan Pendidikan Agama Kristen pada anak dengan pilihan model pembelajaran kontekstual.

\section{Rekomendasi Penelitian:}

Hasil penelitian ini dapat dikembangkan menjadi Penelitian Tindakan Kelas untuk mengetahui keefektivan model pembelajaran kontekstual bagi pelaksanaan Pendidikan Agama Kristen dalam hubungannya dengan nilai-nilai merdeka belajar untuk meningkatkan kedewasaan karakter anak berdasarkan nilainilai kristiani.

\section{Referensi}

Anonymous. "Realita Pendidikan Indonesia Di Masa Pandemi." UII.

-_-. "Spiritual." Kamus Besar Bahasa Indonesia, n.d.

-—-. "Spirituality." Wesbter Dictionary, n.d.

-—_. "Spirituality." Oxford Learner's Dictionary.

Oxford, n.d.

Bagus, Kadek Agus Prama \& Dewa. Merancang 
Penilaian Otentik. Jembrana: Media Educations, 2019.

Brummulen, Harro van. Batu Loncatan Kurikulum Berdasarkan Alkitab. Tangerang: UPH Press, 2008.

Chan, Simon. Spiritual Theology. Studi Sistematik Tentang Kehidupan Kristen. Yogyakarta: Yayasan ANDI, 2002.

Coles, Robert. Menumbuhkan Kecerdasan Moral Pada Anak. Jakarta: Gramedia, 2000.

Crapps, Robert W. Perkembangan Keperibadian \& Keagamaan. Yogyakarta: Kanisius, 1994.

Dharmaputera, Eka. "Agama Dan Spiritualitas: Suatu Perspektif Pengantar.” PENUNTUN III, no. Jurnal Teologi dan Pelayanan (n.d.).

Erickson, Milard J. Teologi Kristen. Malang: Gandum Mas, 2003.

Groome, Thomas. Christian Religious Education. Edited by Daniel Stefanus. Jakarta: BPK Gunung Mulia, 2010.

Heuken, Adolf. Spiritualitas Kristiani. Pemekaran Hidup Rohani Selama Dua Puluh Abad.

Yogyakarta: Yayasan Cipta Loka Caraka, 2002.

Hurlock, Elisabeth. Psikologi Perkembangan: Suatu Pendekatan Sepanjang Rentang Kehidupan. Edited by Ridwan Max Sijabat. Kelima. Jakarta: Erlangga, 1980.

J. Knox Chamblin. Paulus Dan Diri: Ajaran Rasuli Bagi Keutuhan Pribadi. Edited by Jeane Ch. Obadja. Surabaya: Momentum, 2020.

Jr., M. Robert Mulholland. Panggilan Ziarah. Bagaimana Mengembangkan Spiritualitas Yang Holistik. Yogyakarta: Penerbit ANDI, 2002.

Kemendikbud. "Undang-Undang Nomor 14 Tahun 2005 Tentang Guru Dan Dosen, Bab II Pasal VI." Kemendikbud.

---. "Undang-Undang Nomor 20 Tahun 2003

Tentang Sistem Pendidikan Nasional."

M. Sukri Nur dan Aep S. Uyun. Tinjauan Pustaka Sistematis. Bogor: Lakeisha, 2020.

Mahrofi, Zubi. "Indef: Himbauan Pemerintah Harus Jadi Perhatian Pengusaha."

ANTARANEWS.

Mardiharto, Mardiharto. "Pembangunan Sumber Daya Manusia Melalui Bidang Pendidikan Agama Kristen.” PASCA : Jurnal Teologi dan Pendidikan Agama Kristen 15 (2019): 28-32.

---. "Pola Asuh Pendidikan Kerohanian Pada Anak." PASCA : Jurnal Teologi dan Pendidikan
Agama Kristen 15, no. 1 (2019): 23-27.

Munawaroh, Isniatun. "Tantangan Guru Digital Immigrant Saat Pandemi Covid-19.” Krjogja.Com,.

Nursapia Harahap. "Penelitian Kepustakaan." IQRA 08, no. 01 (2014).

Otib Satibi Hidayat. Metode Pengembangan Moral Dan Nilai-Nilai Agama. Edited by Nurul Hikmah. Kesatu. Banten: Universitas Terbuka, 2015.

Paul Hidayat. Hidup Dalam Ritme Allah. Edited by James C. Pantou. Jakarta, 2005.

Pengelola Web Kemdikbud. "Kemendikbud Terbitkan Pedoman Penyelenggaraan Belajar Dari Rumah.” Jakarta, 28 Mei 2020.

Prayitno. Dasar Dan Teori Praksis Pendidikan. Jakarta: Grasindo, 2009.

Ratumanan, T.G. Inovasi Pembelajaran.

Mengembangkan Kompetensi Peserta Didik Secara Optimal. Yogyakarta: Ombak, 2015.

Reni Susani. "Perhatikan, 3 Dampak Pandemi Covid-19 Terhadap Anak.” KOMPAS.

Rizal, Jawahir Gustav. "Realita Pendidikan Indonesia Di Masa Pandemi.” KOMPAS.

Rusman. Model-Model Pembelajaran. Mengembangkan Profesionalisme Guru. Kedua. Jakarta: RajaGrafindo Persada, 2016.

Sari, Milya; Asmendri. "Penelitian Kepustakaan (Library Research) Dalam Penelitian Pendidikan IPA.” Natural Science (2020).

Stevens, R. Paul. Down to Earth. Spiritualitas Yang Membumi. Edited by Nicholas Kurniawan. Kesatu. Malang: Literatur SAAT, 2009.

Walton, Andrew Hill; John. Survei Perjanjian Lama. Malang: Gandum Mas, 1996.

Wolterstorff, Nicholas P. Mendidik Untuk Kehidupan. Surabaya: Momentum, 2020.

Yusuf, Muri. Asesmen Dan Evaluasi Pendidikan. Pilar Penyedia Informasi Dan Kegiatan Pengendalian Mutu Pendidikan. Jakarta: Kencana, 2015 .

Zaluchu, Sonny Eli. "Metode Penelitian Di Dalam Manuskrip Jurnal Ilmiah Keagamaan.” Jurnal Teologi Berita Hidup 3, no. 2 (March 25, 2021): 249-266. https://ejournal.sttberitahidup.ac.id/index.php/jbh/article/ view/93.

--—. "Spiritual Kristiani Di Tengah Laju Peradaban Digital [Spiritual Christianity in the Middle of Digital Civilization].” Proceedings Seminar Nasional Fakultas Psikologi Universitas 
Kristen Satya Wacana dan Asosiasi Psikologi Kristiani [Proceedings of the National Seminar of the Satya Wacana Christian University Psychology Faculty and the Christian Psychology Association] 1, no. 1 (2019): 198-209.

https://repository.uksw.edu/bitstream/123456789 /19648/1/PROS_Sonny Zaluchu_Spiritual Kristiani di Tengah Laju Peradaban Digital.pdf.

Zed, Mestika. Riset Kepustakaan. Jakarta: Yayasan Obor Indonesia, 2008. 